\title{
MEDIASI KEPUASAN KERJA PADA HUBUNGAN ANTARA STRES KERJA DAN KEPUASAN HIDUP KARYAWAN PERUSAHAAN PERMINYAKAN
}

\author{
Susi Widjajani \\ Pika Handayani \\ Universitas Proklamasi 45 Yogyakarta \\ e-mail: susi_wijayani@yahoo.co.id
}

\begin{abstract}
ABSTRAK
This study to determine (1) whether the job stress has a significant influence on life satisfaction (2) whether the job stress has a significant influence on job satisfaction (3) whether the job satisfaction has a significant influence on life satisfaction and (4) whether the job satisfaction mediates the relationship between job stress and life satisfaction. The object of this study is PT. Chevron Pacific Indonesia, located in Riau Rumbai. In this study, the population are employees office at PT. Chevron Pacific Indonesia, Riau Rumbai. Kinds of data which werw collected, consist of primary data and secondary data. This study uses purposive sampling techniques with 204 respondents. Data analysis was done by using path Analysis with the help of software, SPSS 18.0, for windows. The results obtained are as follows: There is no relation between job stress on life satisfaction, between job stress and job satisfaction, and indirect relation on job stress and life satisfaction through the mediation of job satisfaction.
\end{abstract}

Keywords: Job stress, Job Satisfaction, and Life Satisfaction

\section{PENDAHULUAN}

Manfaat bekerja bagi individu adalah untuk memperoleh status sosial, peluang untuk pengembangan pribadi, integrasi, serta memperoleh uang yang cukup untuk memenuhi kebutuhan (Gallie, 2002). Namun, banyak orang bekerja dengan tujuan awal untuk memperoleh kepuasan dan mendapatkan uang untuk memenuhi kebutuhan hidup.

Di dunia kerja tidak selalu sejalan seperti yang dibayangkan oleh para pekerja. Para pekerja dihadapkan dengan berbagai macam persoalan, seperti ketika tuntutan pekerjaan yang tidak konsisten dengan sumber daya yang ada, ketidakcocokan terhadap rekan kerja, lingkungan kerja yang tidak nyaman, rotasi waktu kerja (shiftwork)yang tidak sesuai, tekanan dariberbagai pihak, baik dari atasan, target, deadline, sehingga mereka yang tidak mampu melakukannya, harus bersiap-siap untuk terdepak keluar dari dunia kerja tersebut. Kondisi-kondisi ini menimbulkan perasaan tertekan bagi individu.

Akhirnya dunia kerja yang semula dicari untuk mendapatkan kepuasan hidup, pada titik tertentu berbalik menjadi tempat yang menimbulkan ketertekanan mental, menguras energi fisik maupun psikis individu-individu yang berada didalamnya. Sehingga hal-hal tersebut dapat menimbulkan stres kerja bagi individu yang bekerja. 
Menurut Robbin (2003), stres kerja merupakan kondisi dinamis dimana seorang individu dihadapkan dengan kesempatan, keterbatasan atau tuntutan yang tidak sesuai dengan harapan dari hasil yang ingin individu capai dalam kondisi penting dan tidak menentu. Stres kerja muncul ketika lingkungan yang dianggap penting oleh individu sebagai hal yang sangat menuntut, atau melebihi kemampuannya untuk dapat memenuhi tuntutan tersebut. Stres kerja tidak hanya adanya tuntutan dari lingkungan, tetapi bagaimana individu menilai tuntutan tersebut. Stres kerja muncul bila individu menganggap tuntutan itu penting, menganggap tuntutan tersebut berat, dan melampaui kemampuan dirinya.

Stres kerja merupakan satu persoalan serius yang dihadapi oleh karyawan. Kemampuan individu untuk mencapai kepuasan kerja dalam dunia kerja akan tercapai apabila individu mengembangkan kemampuan untuk mengatasi stres kerja yang dihadapinya. Menurut Faragher dan Cooper (2001) individu yang mengalami stres kerja dapat menyebabkan kepuasan kerja rendah.

Kepuasan kerja menunjukkan kesesuaian terhadap apa yang diharapkan individu dalam bekerja. Kepuasan kerja karyawan merupakan salah satu aspek penting yang perlu diperhatikan dalam usaha peningkatan kualitas sumber daya manusia suatu perusahaan karena karyawan merupakan aset perusahaan yang sangat berharga yang harus dikelola dengan baik oleh perusahaan agar memberikan kontribusi yang optimal. Jika kepuasan kerja karyawan terpenuhi, maka stres kerja karyawan cenderung rendah. Sebaliknya, ketidakpuasan dalam bekerja akan mengakibatkan stres kerja yang tinggi, sehingga akan mengakibatkan tingginya tingkat keluar masuk karyawan, ketidakhadiran, pemogokan, dan tindakan-tindakan negatif lainnya yang dapat merugikan perusahaan.

Kepuasan kerja mencerminkan perasaan seseorang terhadap pekerjaannya dan segala sesuatu di lingkungan pekerjaannya. Handoko (1995) mengatakan, karyawan yang tidak memperoleh kepuasan kerja tidak akan pernah mencapai kematangan psikologis dan pada gilirannya akan mengalami stres kerja. Sehingga dapat di asumsikan karyawan yang tidak mendapatkan kepuasan kerja dalam bekerja akan mengalami stres kerja. Dan sebaliknya karyawan yang memperoleh kepuasan kerja dalam bekerja, stres kerjanya akan berkurang. Dengan mengetahui tingkat kepuasan karyawan, diharapkan perusahaan dapat mengurangi tingkat stres kerja karyawannya.

Sejumlah penelitian menemukan bahwa stres kerja mempengaruhi kepuasan kerja karyawan (Coleman,1976). Beberapa penelitian telah mencoba untuk menentukan hubungan antara stres kerja dan kepuasan kerja. Menurut Stamps dan Predmonte (1986), kepuasan kerja memiliki hubungan yang signifikan terhadap stres kerja. Salah satu dokter umum di Inggris mengidentifikasi stres kerja sebagai salah satu faktor dari ketidakpuasan kerja (Cooper,et al,1989).

Dalam studi lain, Vinokur-Kaplan (1991) menyatakan faktor stres kerja berhubungan negatif dengan kepuasan kerja. Flectcher dan Payne (1980) mengidentifikasikan bahwa kurangnya kepuasan kerja dapat menjadi sumber stres kerja. Sementara kepuasan kerja yang tinggi dapat mengurangi dampak stres kerja. Studi Lands Bergis (1988) menunjukkan bahwa tingkat stres kerja yang tinggi mengakibatkan tingkat kepuasan kerja rendah. Selain itu, Cummins (1990) juga menekankan bahwa stres kerja adalah prediktor dari ketidakpuasan kerja dan kecenderungan lebih besar untuk meninggalkan organisasi. Selain itu kepuasan kerja juga mempunyai arti penting untuk aktualisasi diri karyawan.

Karyawan yang tidak mendapatkan kepuasan kerja tidak akan mencapai kematangan psikologis. Aspek-aspek yang dapat membentuk 
kepuasan kerja karyawan antara lain: faktor individual (umur, jenis kelamin, sikap pribadi terhadap pekerjaan), faktor hubungan antar karyawan (hubungan antarmanajer dan karyawan, hubungan sosial antara sesama karyawan, sugesti dari teman sekerja, faktor fisik, kondisi tempat kerja, emosi dan situasi kerja), faktor exsternal (keadaan keluarga, rekreasi, pendidikan). Aspek-aspek dari faktor exsternal tersebut akan berdampak terhadap kepuasan hidup karyawan.

Caleb dan Bart (2007), pernah melakukan penelitian tentang stres kerja dan kepuasan hidup. Hasil penelitian ini mengatakan bahwa stres langsung berdampak terhadap kepuasan hidup individu. Hasil penelitian ini konsisten dengan temuan sebelumnya, yang menunjukan bahwa stres, terutama ketika berhubungan dengan masalah pekerjaan, dapat menyebabkan seseorang untuk menunjukkan tanda-tanda ketidakpuasan dalam bekerja, merasa tidak mampu melakukan pekerjaan, dan menjadi kurang puas dengan hidup secara keseluruhan (Savicki dan Cooley, 1983).

Kepuasan merupakan hal yang bersifat individual, setiap individu memiliki tingkat kepuasan yang berbeda-beda. Karena itu, tolok ukur yang mutlak dalam mengukur tingkat kepuasan tidak ada (Hasibuan, 2003). Mengukur tingkat kepuasan karyawan bisa dengan mengetahui perasaan karyawan terhadap aspek-aspek dalam pekerjaannya. Karena hal tersebut merupakan upaya untuk mencapai kepuasan hidup serta mencapai kepuasan kerja dilingkungan kerja yang optimal.

Kepuasan hidup disebut sebagai penilaian dari keseluruhan hidup seseorang. Diener et al., (1985) mendefinisikan kepuasan hidup sebagai proses terhadap perbandingan keadaan seseorang dengan apa yang dianggap standar yang tepat didalam hidup. Namun, salah satu asumsi utama dalam penelitian kepuasan kehidupan adalah bahwa penilaian utama kepuasan itu didasarkan pada individu itu sendiri. Langkah-langkah yang didefinisikan oleh para ahli bahkan tidak dapat mengukur kepuasan hidup individu.

Dengan demikian, individu diyakini untuk membangun sebuah penilaian apa yang dapat membuat hidup mereka memuaskan. Dalam sebuah studi Melendez et al, (2007) menemukan bahwa kesejahteraan fisik dan psikologis adalah prediktor utama dari kepuasan hidup. Stres kerja berpengaruh terhadap kepuasan hidup.

Karyawan yang mengalami stres kerja mengakibatkan rendahnya kepuasan kerja, sehingga berdampak terhadap kepuasan hidup. Sehingga dapat dikatakan bahwa kepuasan kerja menjadi mediasi dari hubungan antara stres kerja dan kepuasan hidup. Woei Lian et al (2007) dalam penelitiannya mengatakan bahwa, stres kerja memiliki efek negatif pada kepuasan hidup. Sementara kepuasan kerja memiliki efek positif terhadap kepuasan hidup. Sejauh ini penelitian mengatakan stres kerja yang tinggi ditemukan pada karyawan-karyawan yang bekerja di perusahaan-perusahaan besar. Berdasarkan hal -hal tersebut diatas, maka tujuan dari studi ini adalah untuk menguji pengaruh stres kerja terhadap kepuasan hidup, dimana kepuasan kerja memediasi hubungan diantara kedua variabel tersebut.

\section{REVIEW LITERATUR DAN HIPOTESIS}

\section{Stres Kerja Dan Kepuasan Hidup}

Penemuan dari hasil Silami Mutiu (2012) terdapat korelasi negatif antara stres kerja dan kepuasan hidup. Para pekerja yang mengalami stres kerja yang rendah di tempat kerja hidupnya memuaskan. Hasil penemuan ini dihubungkan dengan penemuan Woei et Liam Al, ( 2007) dimana terdapat suatu hubungan antara stres pekerjaan dan kepuasan hidup. Fletcher dan Payne, (1980) mengidentifikasi bahwa kurangnya kepuasan dapat menjadi sumber stres, sementara kepuasan yang tinggi dapat mengurangi efek dari stres. Dalam sebuah studi oleh Melendez et al, 
(2007) ditemukan bahwa kesejahteraan fisik dan psikologi adalah prediktor utama dari kepuasan hidup. Individu yang mengalami stres berarti kecenderungan mengalami masalah psikologis yang selanjutnya mempengaruhi kepuasan hidup individu tersebut. Kepuasan hidup juga ditemukan terkait terhadap kesehatan fisik dan mental yang baik (Veen Hoven, 1991). Popularitas stres kerja juga memberikan kontribusi untuk kepuasan hidup secara keseluruhan (Locke, 1976). Berdasarkan uraian diatas tersebut, maka dirumuskan hipotesis sebagai berikut ini :

Hipotesis 1 : Stres kerja berpengaruh negatif pada kepuasan hidup

\section{Stres Kerja dan Kepuasan kerja}

Beberapa peneliti telah mencoba untuk menentukan hubungan antara stres kerja dan kepuasan kerja (Williams dan Wong,1999). Stres kerja dan kepuasan kerja adalah dua hal penting dalam penelitian sumber daya manusia. Dalam studi Stamps dan Peedmonte (1986) di temukan bahwa kepuasan kerja memiliki hubungan signifikan dengan stres kerja. Cooper,et al (1989) mengatakan empat jenis stres kerja yang diprediksi sebagai faktor munculnya ketidakpuasaan kerja. Dalam studi lain, Vinokur dan Kaplan, (1991) menyatakan faktor-faktor organisasi, seperti beban kerja dan kondisi kerja secara negatif berhubungan dengan kepuasan kerja.

Fletches dan Payne (1980) menemukakan bahwa kurangnya kepuasan kerja dapat menjadi sumber stres, sementara kepuasan kerja yang tinggi dapat mengurangi efek stres. Penelitian ini mengungkapkan bahwa stres kerja dan kepuasan kerja yang ditemukan saling terkait. Penelitian sebelumnya menyatakan bahwa kepuasan kerja dipengaruhi berbagai faktor, seperti suasana hati yang berdampak pada perilaku seseorang, misalnya terhadap organisasi (Williams dan Wong, 1999 ; William et al, 2000).

Studi Lalndesdergis (1988) menunjukan tingkat stres yang tinggi, terkait dengan rendahnya tingkat kepuasan kerja. Selain itu,
Commins, (1990) telah menekankan bahwa stres kerja adalah prediksi dari ketidakpuasan kerja dan kecenderungan lebih besar untuk meninggalkan organisasi. Babgi de dan Akintay (2011) menunjukkan stres kerja sangat mempengaruhi tingkat kepuasan kerja. Studi Igharia dan Greenhause (1992) juga mengungkapkan bahwa stres kerja mempengaruhi kepuasan kerja. Koslow Sky et al., (1995) menyimpulkan bahwa ada hubungan yang pasti antara dua variabel stres kerja dan kepuasan kerja. Atas dasar hasil penelitian pada hubungan antara stres kerja dan kepuasan kerja, maka disusun hipotesis sebagai berikut :

Hipotesis 2 : Stres kerja berpengaruh negatif pada kepuasan kerja

\section{Kepuasan Kerja dan Kepuasan Hidup}

Wilensky (1960) menyatakan orang yang puas terhadap pekerjaannya akan memiliki kehidupan yang memuaskan dan sebaliknya. Artinya bahwa terdapat hubungan positif antara kepuasan kerja dan kepuasan hidup. Bukti hubungan kepuasan hidup dan kepuasan kerja cukup rendah namun konsisten positif. Berbagai tekhnik statistik, seperti model persamaan struktural (Schnitt dan Bederan, 1982) telah digunakan untuk mengeksplorasi arah hubungan kepuasan kerja dan kepuasan hidup. Beberapa peneliti telah mengemukakan kepuasan kerja akan lebih banyak dipengaruhi oleh kepuasan hidup dari pada sebaliknya (Near et al,1978) sementara yang lain melaporkan bahwa kepuasan hidup lebih banyak dipengaruhi oleh kepuasan kerja.

Selain itu, berbagai penelitian telah mengungkapkan hubungan timbal balik dimana ada hubungan dua arah diantara kepuasan hidup dan kepuasan kerja (Schmitt dan Bedaian, 1982). Popularitas stres kerja juga memberikankontribusi untuk kepuasan hidup secara keseluruhan (Locke, 1976). Hasil studi lain mengemukakan bahwa jenis pekerjaan dapat berdampak besar pada kepuasan hidup dan kepuasan kerja. Namun 
demikian, hipotesis dalam penelitian ini adalah sebagai berikut :

Hipotesis 3 : Kepuasan kerja berpengaruh positif pada kepuasan hidup

\section{Mediasi Kepuasan Kerja Pada Hubungan Antara Stres Kerja dan Kepuasan Hidup}

Gibson et al, (1996) menyatakan bahwa stres kerja adalah permintaan psikologis atau fisik yang berlebihan kepada seseorang. Dalam sebuah studi oleh Melendez et al, (2007) ditemukan bahwa kesejahteraan psikologis dan fisik adalah prediktor utama dari kepuasan hidup. Berbeda dengan hasil dari Silami Mutiu (2012) dimana terdapat korelasi negatif antara stres kerja dan kepuasan hidup.

Dalam studi Stamps dan Peedmonte (1986) menemukan hubungan signifikan antara stres kerja dengan kepuasan kerja. Dan terdapat hubungan positif antara kepuasan kerja terhadap kepuasan hidup (Wilensky, 1960). Karyawan yang mengalami stres kerja dapat mengakibatkan ketidakpuasan dalam bekerja, sehingga mengakibatkan kepuasan hidup menjadi rendah. sedangkan menurut Locke (1976), popularitas stres kerja memberikan kontribusi untuk kepuasan hidup secara keseluruhan. Selenjutnya dalam penelitian ini, disusun hipotesis sebagai berikut :

H4 : Kepuasan kerja memediasi hubungan antara stres kerja dengan kepuasan hidup

Berdasarkan pengaruh antara variabel secara teoritis tersebut dapat dibuat model dalam bentuk diagram jalur sebagai berikut :

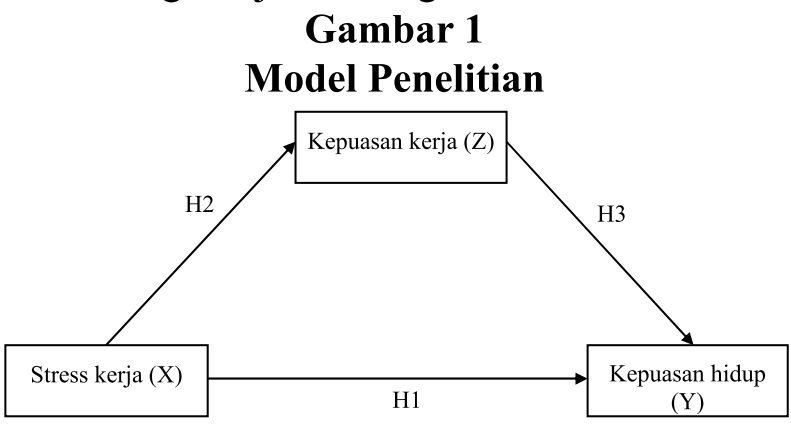

\section{METODE PENELITIAN}

Obyek dari penelitian ini adalah $P T$. Chevron Pacific Indonesia yang berlokasi di Rumbai Riau. Data diperoleh survei lapangan dengan cara menyebarkan kuesioner dan melakukan wawancara dengan narasumber secara langsung di lokasi penelitian. Tekhnik pengambilan sampel menggunakan purposive sampling dengan kriteria karyawan staf kantor yang telah bekerja $>6$ bulan, karena masa kerja dibawah 6 bulan dianggap masa percobaan kerja. Data kuesioner yang digunakan sejumlah 204 responden dari total 250 kuesioner yang disebar. Hal ini berarti respon rate dari penelitian ini sebesar 81,6\%. Analisis data dilakukan dengan menggunakan Path Analysis (Analisis jalur) dengan bantuan software SPSS 16.0 for windows.

\section{Definisi Operasional dan Pengukuran Variabel}

Variabel stres kerja, menurut Ivancevich dan Mattteson dalam Luthans (2006) diartikan sebagai interaksi individu dengan lingkungan, tetapi kemudian diperinci lagi menjadi respon adaptif yang dihubungkan oleh perbedaan individu atau proses psikologi yang merupakan konsekuensi tindakan, situasi, atau kejadian eksternal (lingkungan) yang menempatkan tuntutan psikologis atau fisik secara berlebihan pada seseorang. Dimensi yang digunakan dalam pengukuran variabel stres keja menggunakan pendapat dari Mas'ud (2004) dimensi tersebut adalah skala kesan stres (meliputi skala kesan stres ekstraorganisasi, skala kesan stres organisasi, skala kesan stres kelompok) dan skala stressor individual. Kuesioner stres kerja memiliki tujuh skala likert mulai dari sangat tindak setuju sekali yang bernilai 1 sampai dengan sangat setuju sekali yang bernilai 7 . Kuesioner terdiri dari 12 item pertanyaan, yang terbagi dalam skala stres ekstraorganisasi sebanyak 3 item pertanyaan, skala stres organisasi sebanyak 3 item pertanyaan, skala stressor individu sebanyak 3 item pertanyaan, item skala stres kelompok sebanyak 3 item. 
Variabel kepuasan kerja, menurut Robbins (2003) diartikan sebagai sikap umum seseorang individu terhadap pekerjaannya. Dimensi yang digunakan dalam pengukuran variabel kepuasan kerja menggunakan pendapat dari Davis (2006), yaitu turn over, tingkat kehadiran, usia, tingkat pekerjaan, umur organisasi, dan kompensasi yang layak. Kuesioner kepuasan kerja dinilai dengan menggunakan 7 skala likert mulai dari sangat tidak setuju sekali yang bernilai 1, sampai dengan sangat setuju sekali yang bernilai 7 . Kuesioner terdiri dari tiga puluh item pertanyaan, yang terbagi dalam turn over sebanyak 4 item pertanyaan, tingkat kehadiran sebanyak 3 item, usia sebanyak 4 item, tingkat pekerjaan sebanyak 7 item, ukuran organisasi sebanyak 5 item, dan kompensasi yang layak sebanyak 7 item.

Kepuasan Hidup adalah penilaian secara keseluruhan perasaan dan sikap kehidupan seseorang pada suatu titik waktu tertentu. Menurut Diener (1985) kepuasan hidup mengacu pada aspek keseluruhan kesejahteraan subjektif, dan cenderung mempengaruhi segala sesuatu disekitar individu. Dimensi yang digunakan dalam pengukuran variabel kepuasan hidup menggunakan pendapat dari Diener et al (1985), yaitu: waktu, ekonomi, dan sosial. Kuesioner kepuasan hidup memiliki 7 skala likert mulai dari sangat tidak setuju sekali (nilai 1) sampai dengan sangat setuju sekali yang bernilai 7. Kuesioner terdiri dari 5 item pertanyaan, yang terbagi dalam waktu sebanyak 2 item pertanyaan, ekonomi dan sosial sebanyak 3 item pertanyaan.

\section{HASIL PENELITIAN DAN PEMBAHASAN}

Karakteristik responden dalam penelitian ini meliputi jenis kelamin, usia, masa kerja, pendidikan, gaji, status perkawinan, jumlah anak, dan unit kerja. Responden dalam penelitian ini $73 \%$ adalah laki - laki, dengan usia rata - rata antara 41 - 50 tahun, dan berasal dari berbagai departemen. Pendidikan responden mayoritas S1 dengan angka 78,9\%, dan masa kerja lebih dari 15 tahun.

Pengujian validitas dilakukan dengan metode korelasi product moment dari Pearson. Hasil validitas menunjukkan ada tiga item pertanyaan yang tidak valid dalam kuesioner. Masing-masing berasal 2 item dari variabel kepuasan kerja dan 1 item dari variabel kepuasan hidup. Dan sehingga yang dapat digunakan untuk analisis data berikutnya hanya berjumlah 44 item perntanyaan. Pengujian reliabilitas dilakukan dengan teknik Cronbach's alpha. Hasil menunjukkan semua variabel adalah reliabel.

Pengolahan statistik deskriptifmeliputi ratarata (mean), standar deviasi dan korelasi. Tabel 1 berikut menunjukkan hasil deskriptif statistik dan korelasi antar konstruk, sebagai berikut:

Tabel. 1

Statistik Deskriptif Data

\begin{tabular}{|c|c|c|c|}
\hline \multirow{2}{*}{$\begin{array}{c}\text { Variabel } \\
\text { SK }\end{array}$} & \multicolumn{3}{|c|}{ Koefisien Korelasi } \\
\hline & KH & KK & \\
\hline Stres Kerja (SK) & 1 & $-0,412 * *$ & $-0,589 * *$ \\
\hline $\begin{array}{l}\text { Kepuasan Hidup } \\
(\mathrm{KH})\end{array}$ & & 1 & $0,721^{* *}$ \\
\hline $\begin{array}{l}\text { Kepuasan Kerja } \\
(\mathrm{KK})\end{array}$ & & & 1 \\
\hline Mean & 2,4105 & 5,4730 & 5,3992 \\
\hline Std. Deviation & 0,79566 & 0,85162 & 0,68249 \\
\hline Minimum & 3,00 & 4,00 & 4,92 \\
\hline Maximum & 7,00 & 7,00 & 4,29 \\
\hline
\end{tabular}

** Correlation is significant at the 0.01 level (2-tailed).

Sumber: hasil olah data

Hasil pengolahan data (tabel. 1) menunjukkan bahwa nilai rata-rata untuk jawaban stres kerja adalah 2,4105 dan standar deviasi 0,79566. Hal ini mengindikasikan bahwa responden memiliki tingkat stres kerja yang 
rendah dengan variasi jawaban yang rendah. Rata-rata jawaban untuk Kepuasan Kerja adalah 5,3992 dan standar deviasi 0,68249, artinya responden memiliki Kepuasan Kerja yang cukup tinggi dengan variasi jawaban yang rendah. Nilai rata-rata untuk stres kerja lebih rendah dari kepuasan hidup adalah 5,4730, dan standar deviasi 0,79566 , artinya responden memiliki kepuasan hidup yang cukup tinggi dengan variasi jawaban yang rendah. Hasil ini menjelaskan bahwa secara umum responden tidak mempersepsikan adanya stress dalam bekerja, dan hasil juga menunjukkan bahwa karyawan memiliki kepuasan kerja dan kepuasan hidup yang tinggi. Korelasi antar kepuasan kerja dan kepuasan hidup menunjukkan korelasi yang tertinggi dibandingkan korelasi konstruk yang lain. Korelasi kepuasan kerja dan kepuasan hidup adalah 0,721 (signifikan pada level $\alpha=0,01$ ). Korelasi antara stres kerja dan kepuasan hidup juga signifikan dengan nilai $r=$ $-0,412$. Selain itu stres kerja juga berkorelasi dengan kepuasan kerja dengan nilai $\mathrm{r}=-0,589$. Hasil ini menunjukkan bahwa semua konstruk yang diuji saling memiliki hubungan korelasi terhadap satu dengan yang lain.

Berikut ini tabel hasil perhitungan Regresi Linier Model Jalur dengan metode OLS (Ordinary Least Square) berdasar persamaan dari model yang telah disusun :

Tabel. 2

\begin{tabular}{|c|c|c|c|c|c|c|}
\hline \multirow{2}{*}{ Variabel } & \multicolumn{3}{|c|}{ Kepuasan Kerja } & \multicolumn{3}{|c|}{ Kepuasan Hidup } \\
\hline & $\beta$ & $\mathrm{T}$ & $P$ & $\beta$ & $\mathrm{t}$ & $P$ \\
\hline Stres kerja & $-0,589$ & $-10,360$ & ,000 & 0,011 & $-0,412$ & 0,749 \\
\hline $\begin{array}{l}\text { Kepuasan } \\
\text { Kerja }\end{array}$ & & & & 0,732 & 12,102 & 000 \\
\hline $\mathrm{R}^{2}$ & \multicolumn{3}{|r|}{0,347} & \multicolumn{3}{|c|}{0,721} \\
\hline Adjusted $\mathrm{R}^{2}$ & \multicolumn{3}{|r|}{0,344} & \multicolumn{3}{|c|}{0,515} \\
\hline $\mathrm{F}$ & \multicolumn{3}{|c|}{107,339} & \multicolumn{3}{|c|}{108,732} \\
\hline
\end{tabular}

Sumber: Hasil Olah Data
Berdasarkan hasil perhitungan pada tabel 2 di atas, nilai standardized beta stres kerja sebesar 0,011 dan signifikan pada 0,749 yang berarti stres kerja tidak mempengaruhi kepuasan hidup. Nilai koefisien standardized beta 0,011 merupakan nilai path atau jalur p1. Dengan demikian berarti hipotesis 1 tidak terbukti. Selanjutnya nilai standardized beta stres kerja menunjukkan angka 0,589 dan signifikan pada angka 0,000 , yang berarti stres kerja berpengaruh negatif terhadap kepuasan kerja. Nilai koefisien standardized beta $-0,589$ merupakan nilai path atau jalur p2. Sehingga dapat disimpulkan bahwa hipotesis 2 terbukti.

Nilai standardized beta kepuasan kerja menunjukkan angka 0,732 dan signifikan pada angka 0,000 , yang berarti kepuasan kerja mempengaruhi kepuasan hidup. Nilai koefisien standardized beta 0,732 merupakan nilai path atau jalur p3. Sehingga dapat disimpulkan bahwa hipotesis 3 terbukti. Hasil analisis jalur menunjukkan bahwa stres kerja tidak dapat berpengaruh langsung ke kepuasan hidup dan dapat juga berpengaruh tidak langsung yaitu dari stres kerja ke Kepuasan Kerja (sebagai variabel mediating). Besaran pengaruh langsung adalah 0,011 sedangkan besarnya pengaruh tidak langsung harus dihitung dengan mengalikan koefisien tidak langsungnya yaitu, $(-0,589)$ $\mathrm{x}(0,732)=-0,432$. Oleh karena koefisien hubungan langsung lebih kecil dari koefisien hubungan tidak langsung, maka dapat dikatakan bahwa hubungan yang sebenarnya adalah tidak langsung. Hal ini menunjukkan bahwa hipotesis 4 terbukti. Bahwa kepuasan kerja merupakan mediasi dari hubungan stres kerja dan kepuasan hidup.

Dan berdasar hasil penghitungan di atas, maka diperoleh model persamaan sebagai berikut: 
Gambar. 2

\section{Model Analisis Jalur Hasil Perhitungan}

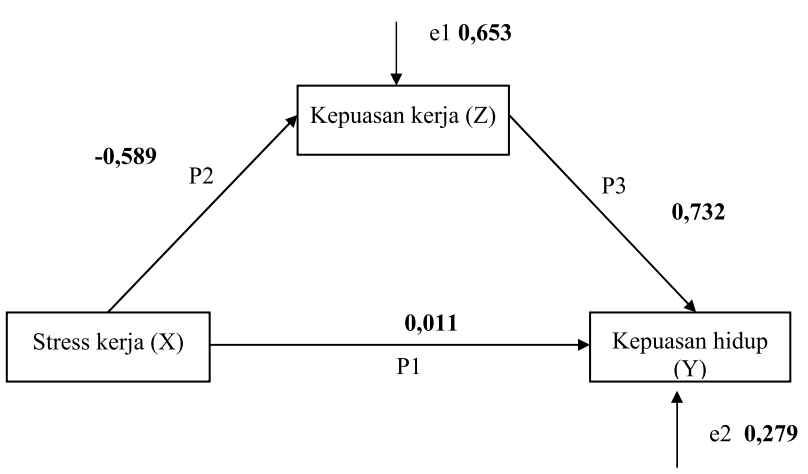

Dalam Analisis Jalur, langkah terakhir yang diambil yaitu dengan menggunakan theory triming, dimana jalur-jalur yang nonsignifikan dibuang. Sehingga diperoleh model yang didukung (konfirmasi) oleh data empirik sebagai berikut:

Gambar. 3

Model Akhir Analisis Jalur

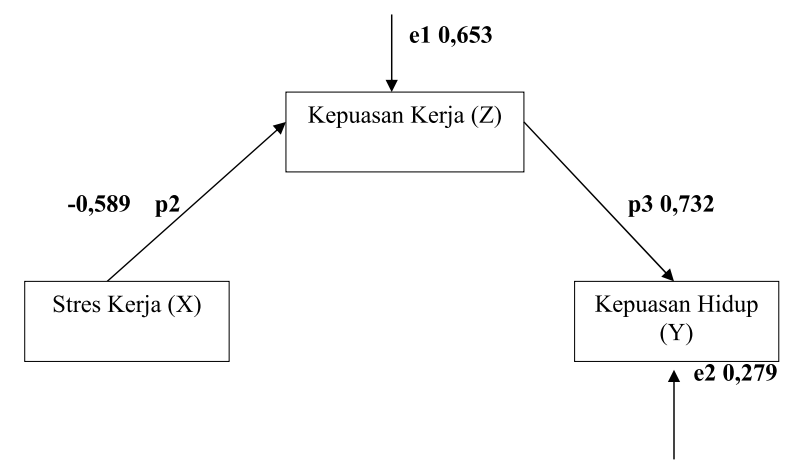

Hasil pengujian hipotesis menunjukkan bahwa ada tiga hipotesis yang terbukti $(\mathrm{H} 2, \mathrm{H} 3$, H4) dan satu hipotesis yang tidak terbukti (H1).

Hipotesis 1 (tidak terbukti) stres kerja berpengaruh negatif pada kepuasan hidup. Kondisi ini tidak mendukung hasil penemuan Silami Mutiu (2012) dimana terdapat korelasi negatif antara stres kerja dan kepuasan hidup. Hal ini sangat dimungkinkan karena stres kerja yang dimiliki oleh karyawan PT CPI relatif kecil. Rendahnya stres kerja karyawan bisa dilihat dari nilai rata-rata untuk jawaban stres kerja adalah 2,4105 dan standar deviasi 0,79566. Sehingga tidak begitu berpengaruh terhadap kepuasan hidupnya. Sudah jamak diketahui bahwa taraf kehidupan karyawan di industri perminyakan relatif tinggi, sehingga rendahnya stres kerja yang dialami karyawan menjadi tidak signifikan berpengaruh. Dimungkinkan justru kondisi sebaliknya yang terjadi dimana kepuasan hidup mempengaruhi stres kerja. Seperti yang tertuang dalam hasil studi Fletcher dan Payne (1980) yang mengidentifikasi rendahnya kepuasan hidup justru dapat menjadi sumber stres, sementara kepuasan hidup yang tinggi dapat mengurangi efek dari stres. Rendahnya stres kerja karyawan PT CPI karena tingginya kepuasan hidup.

Hipotesis 2 terbukti bahwa stres kerja berpengaruh negatif pada kepuasan kerja. Hal ini sependapat dengan hasil penelitian dari Stamps dan Peedmonte (1986) yang menemukan bahwa stres kerja memiliki hubungan signifikan terhadap kepuasan kerja. Tingkat stres yang tinggi terkait dengan rendahnya tingkat kepuasan kerja karyawan. Pada hasil penelitian ini karyawan memiliki tingkat kepuasan kerja yang tinggi.

Hipotesis 3 terbukti bahwa kepuasan kerja dan kepuasan hidup berpengaruh positif. Wilensky (1960) mengatakan yang memiliki kepuasan kerja yang tinggi maka, akan memiliki kepuasan hidup yang tinggi. Hal ini sependapat dengan studi dari Cremer (1995) bahwa jenis pekerjaan dapat berdampak besar pada kepuasan hidup, dan kepuasan kerja membawa kepuasan hidup. Hasil pada hasil penelitian ini, karyawan memiliki tingkat kepuasan hidup dan kepuasan kerja yang cukup tinggi.

Hipotesis 4 terbukti bahwa kepuasan kerja memediasi hubungan pada stres kerja dan kepuasan hidup. Pada penelitian ini hubungan langsung antara stres kerja dan kepuasan hidup tidak memiliki hubungan yang signifikan. 
Dan kepuasan kerja memiliki hubungan yang signifikan terhadap kepuasan hidup. Sehingga dapat disimpulkan bahwa stres kerja tidak berpengaruh secara langsung terhadap kepuasan hidup, tetapi memiliki hubungan secara tidak langsung yaitu melalui adanya kepuasan kerja.

\section{KESIMPULAN DAN SARAN}

Penelitian ini bertujuan untuk menjelaskan pengaruh stres kerja pada kepuasan hidup dengan kepuasan kerja sebagai variabel pemediasi. Dari hasil penelitian dapat disimpulkan bahwa tidak terdapat hubungan antara stres kerja dengan kepuasan hidup, tetapi terdapat hubungan antara stres kerja dengan kepuasan kerja. Selain itu kepuasan kerja juga mempengaruhi kepuasan hidup secara signifikan. Hubungan antara stres kerja dan kepuasan hidup diketahui tidak memiliki hubungan secara langsung, tetapi dimediasi oleh kepuasan kerja.

Berdasarkan hasil simpulan yang diperoleh, maka saran yang dapat diberikan adalah sebagai berikut: pertama, untuk menjaga kepuasan hidup karyawan, maka kepuasan kerja karyawan harus tetap dijaga. Terjaganya kepuasan kerja karyawan bisa dilakukan antara lain dengan mengontrol stres kerja yang dialami oleh karyawan. Kedua, untuk tetap mempertahankan stres kerja karyawan yang rendah, dapat dilakukan dengan menjaga tingkat kepuasan hidup karyawan yang sudah tinggi.

\section{DAFTAR PUSTAKA}

As'ad, M. 2003. Psikologi Industri. Liberty. Yogyakarta.

Babjide, E. O., \& Akintay, I. (2011). Occupational Stress, Psychological Well Being and Workers' Behaviour in Manufacturing Industries in Wouth-West Nigeria. International Journal of Management and Innovation, Vol. 3(Issue 1).
Celeb, Bart. 2007, Optimism, Stress, Life Satisfaction, and Job Burnout in Restaurant Managers. University of Tennessee at Chattanooga, Department of Psychology, Dept. 2803, 615 McCallie Ave., Chattanooga, TN 374032598,USA; Bart-Weathington@utc.edu (e-mail).

Coleman J. C. (1976). Abnormal Psychology and Modern Life (Indian reprint), Iniaporewalla, Bombay.

Cooper, C., U. Rout and B. Faragher. 1989. "Mental Health, Job Satisfaction, and Job Stress Among General Practitioners", $B$ Medical Journal, 298, pp366-370.

Cummins R.C. 1990. "Job stress and the buffering effort of supervisory support", Group and Organizational Studies, 15(1), pp.92-104.

Davis, K dan J.W. Newstrom. 2006. Perilaku Organisasi. Jilid 1, Edisi 7. Terjemahan. Erlangga. Jakarta.

Diener, E. (1985). Subjective wellbeing. Psychological Bulletin, 95, 542-575.

Fletcher, J.B., \& Payne, R. 1980. "Stress and Work: A Review and a Theoretical Framework", Part 1, Personnel Review, 9, pp. 1-20.

Gallie, D. (2002). "The Quality of Working Life in Welfare Strategy." In Gosta Esping Andersen, Duncan Gallie, Anton Hemerijck, and John Myles (eds.): Why We Need a New Welfare State. Oxford, Oxford University Press. p. 96-127.

Gibson, Ivancevich, Donnelly 1996, Organisasi Perilaku, Struktur dan Proses, Binarupa Aksara, Jakarta.

Handoko, Hani. 1998, Manajemen. Yogyakarta : BPFE. Handoko, Luthans, Fred. 2006. Perilaku Organisasi 10th. Edisi Indonesia. Yogyakarta : Penerbit ANDI.

Hasibuan, M.S.P. 2003. Manajemen Sumber Daya Manusia. Edisi Revisi. Bumi Aksara. Jakarta. 
Igharia, Magid and Greenhaus, Jeffrey H. 1992. "Determinants of MIS Employees" turnover intentions: A Structural Equation Model", Communications of the ACM, 35(2), pp.34-49 [21]

Koslowsky, M., Kluger, A., \& Reich, M. 1995. Commuting Stress: Causes, Effects, and Methods of Coping. Plenum, New York.

Landsbergis, P.A. 1988. "Occupational stress among health care workers: A test of the jobdemands- control model", Journal of Organizational Behavior, 9, pp.217239.

Locke, E. A. 1992, The nature and causes of job satisfaction, in M. D. Dunnette (ed.), Handbook of Industrial and Organizational Psychology (Rand McNally, Chicago).

Melendez, J.C., Tomas, J. M., Oliver, A., Navarro, E. (2007). Psychological and physical dimensions explaining life satisfaction among the elderly: A structural model examination. University of Valencia, Av. Blasco Ibanez, 21, 34-56.

Near, J.P., Rice, R.W., \& Hunt, R.G. (1978). Work and extra-work correlates of life and job satisfaction. Academy of Management Journal, 21, 248-264.

Robbins, Stephen P. dan Judge, Timothy A., 2003, Organizational Behaviour 12th edition. Jakarta : Salemba Empat.

Savicki, V., \& Cooley, E. (1983). Theoretical and research considerations of burnout. Children \& Youth Services Review, 5, 227-238.
Schmitt, N., \& Bedeian, A.G. (1982). A comparison of LISREL and two-stage least squares analysis of a hypothesized lifejob satisfaction reciprocal relationship. Journal of Applied Psychology, 67, 808817.

Stamps, P.L., \& Piedmonte, E.B. 1986. Nurses and work satisfaction: An index for measurement. Ann Arbor, MI: Health Administration Press Perspectives.

Veenhoven, R. (1991). Questions on happiness: Classical topics, modern answers, and blind spots. In F. Strack, M. Argyle, \& N. Schwartz (Eds.), Subjective Wellbeing: An Interdisciplinary Perspective (ppl 1-26). Elmsford, NY: Pergamon Press.

Vinokur-Kaplan J.X. 1991. "Job Satisfaction among Social Workers in Public and Voluntary Child Welfare Agencies", Child Welfare, 155, pp. 81-91.

Williams, S. S., \& Wong, T. (1999). Mood and organizational citizenship behaviour: the effects positive affect on employee organizational citizenship behaviour intentions. Journal of Psychology, Vol. 133 (6) 656-66.

Woei Lian, J., Ming Lin, T. \& Kuan Wu, H. (2007). Job stress, job satisfaction and life Stres kerja, kepuasan kerja dan kehidupansatisfaction between managerial and technical is personnel, Proceedings of Business and kepuasan antara manajerial dan teknis personil, Prosiding Bisnis danInformation, Vol. Informasi, Vol. 4, pg 1-17. 4, pg 1-17. 